International Research Journal of Management, IT \& Social Sciences
Available online at https://sloap.org/journals/index.php/irjmis/
Vol. 8 No. 6, November 2021, pages: 619-629
ISSN: 2395-7492
https://doi.org/10.21744/irjmis.v8n6.1958

\title{
Pentagon Fraud Perspective Analysis in Detecting Indications of Financial Statement Fraud
}

\author{
Ni Putu Winda Ayuningtyas a \\ I Putu Sudana ${ }^{b}$ \\ I Wayan Suartana ${ }^{c}$ \\ Ni Putu Sri Harta Mimba ${ }^{d}$
}

Article history:

Submitted: 27 August 2021

Revised: 18 Sept 2021

Accepted: 25 Oct 2021

Keywords:

banking;

financial statement fraud;

fraud pentagon;

multiple linear regression;

non-probability sampling;

\begin{abstract}
This study aims to obtain empirical evidence regarding the elements of fraud pentagon theory on indications of financial statement fraud. This research was conducted on banking companies listed on the Indonesia Stock Exchange (IDX) for the 2017-2020 period. The method of determining the sample used is non-probability sampling with purposive sampling technique. The number of samples that meet the sample selection criteria are 140 samples, namely 35 banking companies during the four years of observation 2017-2020. The data analysis technique used is multiple linear regression. Based on the results of the analysis, it is stated that the nature of industry and change of directors have a negative effect on indications of financial statement fraud, while personal financial need, rationalization, and CEO duality have no effect on indications of financial statement fraud. This study has implications for investors, creditors, the government and other parties who need financial statement information to consider the elements of the fraud pentagon theory to detect indications of fraudulent financial statements in banking companies.
\end{abstract}

International research journal of management, IT and social sciences (C) 2021. This is an open access article under the CC BY-NC-ND license (https://creativecommons.org/licenses/by-nc-nd/4.0/).

\section{Corresponding author:}

Ni Putu Winda Ayuningtyas

Faculty of Economics and Business, Udayana University, Bali, Indonesia.

Email address: windaayuningtyas21@gmail.com

Faculty of Economics and Business, Udayana University, Bali, Indonesia

Faculty of Economics and Business, Udayana University, Bali, Indonesia

Faculty of Economics and Business, Udayana University, Bali, Indonesia

${ }^{1}$ Faculty of Economics and Business, Udayana University, Bali, Indonesia 


\section{Introduction}

The phenomenon of financial statement fraud in banking companies in Indonesia is not the first time that has happened and is still a hot topic that really needs to be discussed and researched until now. The phenomenon of fraud cases that occurred in the banking sector in 2020 was the case of the loss of IDR 22 billion of money belonging to Winda Lunardi, an e-sport athlete, a customer of PT Bank Maybank Indonesia Tbk. PT Bank Maybank Indonesia Tbk (BNII) became a polemic after the disclosure of the case. According to the Chancellor of the Perbanas Institute, Hermanto Siregar, according to the Chancellor of the Perbanas Institute, Hermanto Siregar assessed that there was banking fraud that occurred in the case of burglary of Maybank customers. Fraud case This can happen because of weak internal controls in banking companies so that criminal loopholes in banking still occur today. The existence of a fraud case at PT. Bank Maybank Indonesia Tbk (BNII) has become a hotly discussed case. The impact of these cases not only tarnishes the company's good name, but can have a negative impact on the financial services industry. In addition, the existence of fraud cases at Maybank will also tarnish customer confidence in Maybank (Kustina et al., 2019).

Many cases of the phenomenon of financial statement fraud can harm many parties and will affect the long-term sustainability and reputation of the company. The worst condition that can be experienced by the company as a result of this action is bankruptcy. Fraud cases that occur can be caused by weak internal controls and company risk management. Therefore, fraud cases are an important phenomenon that must be prevented as early as possible. In preventing the possibility of fraud, the auditor can assess and consider from various points of view, one of which is by using the theory of fraud risk factors which was first proposed (Cressey, 1953). Cressey (1953), states that there are three conditions that are always present in fraudulent acts, namely pressure, opportunity, and rationalization or also known as the fraud triangle theory (Skousen et al., 2009). Then, the fraud triangle theory was redeveloped by Wolfe \& Hermanson (2004), into a fraud diamond theory by adding one indicator element, namely the capability element. Furthermore, the theory developed again when Crowe (2011), explained that the element of ego (arrogance) also influences the occurrence of fraud, so that it becomes five elements known as the fraud pentagon which will complete the concept of the fraud triangle and fraud diamond theory (Saunders, 1999; Bikker \& Haaf, 2002).

This study will refer to the fraud pentagon theory developed by Crowe (2011), to detect financial statement fraud that occurs in companies. In research conducted by Puspitha \& Yasa (2018); Antawirya et al. (2019), it is proven that the factors of the fraud pentagon namely pressure, opportunity, rationalization, capability, and arrogance can detect indications of financial statement fraud. The elements of this pentagon fraud cannot be directly investigated so that it requires variable proxies. The first element of the fraud pentagon is pressure. In this study, pressure is proxied by personal financial need. Personal financial need refers to the personal financial needs of managers and company executives who are very dependent on the company's financial condition (Zhou \& Kapoor, 2011; Rezaee, 2005).

Research conducted by Oktafiana \& Sari (2019); Surya et al. (2018), states that personal financial need has a positive effect on the occurrence of fraudulent practices. The existence of pressures such as financial demands, declining economic conditions due to the COVID-19 pandemic and high lifestyles will encourage someone to commit fraud. The worse the personal financial condition of the company executives, the higher the financial dependence of the executives on the company so that fraudulent financial reporting practices tend to occur. Meanwhile, according to Sari \& Nugroho (2021); Kusumaningsih (2017), say that personal financial need has a negative effect on financial statement fraud. When the company's performance is very good and is supported by the financial condition of the executives in terms of share ownership by insiders in the company is very high, the lower the chance of financial statement fraud. The existence of differences in research results makes the personal financial need variable need to be re-examined to find out whether personal financial need makes individuals commit fraud or not (Uyanık \& Güler, 2013; Sousa et al., 2007).

The second element of this fraud pentagon is opportunity. Opportunity to commit fraud can occur when internal control is low and management supervision is weak in the company. Nature of industry is an industrial characteristic that is indicated by ideal industrial conditions. The condition of high cash receipts and receivables can describe the form of a good nature of the industry and can be responded to with different reactions from the company's managers (Suparmini et al., 2020). The nature of industry can provide individuals with opportunities to commit fraud because of industry regulations that require companies to have subjective justification capabilities in calculating estimates on certain accounts. According to Summers \& Sweeney (1998), it is stated that receivables and inventories require subjective assessment and must be wary of because they are often the object of manipulation of financial statements (Mata, 2011; Bai et al., 2014). Rationalization is the third element of the fraud pentagon. Rationalization is related to attitudes that justify fraudulent behavior and are considered normal. The factors that cause financial statement fraud originating from rationalization are related to the unfavorable relationship and different interests between management 
and auditors, management's failure to manage company finances, justifying earnings management behavior in the company, and feeling the most meritorious for the organization. Auditor switching in the company can be used as a measure of rationalization.

Auditor switching in companies causes the new auditors to still not understand the overall condition of the company. So that management can commit and justify fraud that is not detected by external auditors. Research conducted by Loebbecke et al. (1989), explains that the majority of audit failures occur more often at the beginning of the year during the audit engagement period. So that it will make the company change its external auditor and think rationally to do financial statement fraud. This is also similar to the research conducted by Septriani \& Handayani (2018); Putriasih et al. (2016); Mintara \& Hapsari (2021), which also state that rationalization affects financial statement fraud in banking companies. Capability is an element developed by Wolfe \& Hermanson (2004) in the fraud diamond theory to detect financial statement fraud. Fraud can occur because someone has more ability or capability to commit fraud for the realization of certain goals. Capability is influenced by several factors such as positioning, intelligence and creativity, ego or confidence, coercive skills, deceit, and stress. The main factor that can be seen to judge that someone has a large enough capability is positioning. Positioning is the position and function of a person in the company that tends to make it a gap to commit fraud. Therefore, high positions or executives are considered the most capable of reducing fraud or they may even take advantage of their ability to commit fraud (Topp et al., 2004; Reinhart \& Rogoff, 2013).

Variable director change associated with the element capability. Director changes is the delegation of duties and authority from the old board of directors to the new board of directors with the aim of improving the performance of the previous directors who were less competent in overseeing the company's activities. A change of more competent directors is considered to be able to oversee the company's operations well to reduce fraud (Mintara \& Hapsari, 2021). Putriasih et al. (2016), use director change as a measuring tool for capability to determine whether or not there is a potential for fraudulent financial statements. Research conducted by Putriasih et al. (2016); Siddiq et al. (2017); Septriani \& Handayani (2018), both prove that director change can be used to detect financial statement fraud. Arrogance is the last element as a complementary element to the fraud pentagon theory proposed (Crowe, 2011). Arrogance is related to the character of someone who feels that he is in charge of everything in the company. The attitude and behavior of arrogance can cause someone dared to commit fraud behavior because he has power and assume that the internal controls and regulations in effect at the company would not apply to him so that they would be free to fraud. Arrogance is usually related to the CEO or directors who have high or powerful positions in a company such as because all operational activities in the company must be with the CEO's approval. In this study, the element of arrogance will be measured by CEO duality or CEO who has many positions (dual positions) both inside and outside the company. If the CEO holds multiple positions, it shows that the CEO has a strong influence and has an important role in company policy, so that dual positions are included in arrogance. A good performance company should not have a CEO who has multiple positions (CEO duality) within the company. CEO duality can encourage someone to commit collusion, sacrifice the interests of shareholders, and even cause the work of directors to be ineffective because they have double busyness so that it can increase the occurrence of fraud in the company. The above statement is also supported by research conducted by Dechow et al. (2012), which shows that financial statement fraud related to earnings manipulation is dominated by management and dual positions by the CEO (Mehta, 2016; Rengganis et al., 2019).

\section{Literature review and hypotheses development}

The number of shareholdings of people in the company shows the company's good financial performance as well as the financial supervision function and the implementation of good corporate governance in the company so that executives will not worry about personal financial needs within the company so that financial statement fraud will decrease within the company. So, if the insider's share ownership in the company is very high, the lower the chances of an indication of financial statements in the company. Kusumaningsih (2017); Sari \& Nugroho (2021), also explain that personal financial need has a negative effect on financial statement fraud. When the company's performance is very good and is supported by the financial condition of the executives in terms of share ownership by insiders in the company is very high, the lower the chance of financial statement fraud.

Ayuningtyas, N. P. W., Sudana, I. P., Suartana, I. W., \& Mimba, N. P. S. H. (2021). Pentagon fraud perspective analysis in detecting indications of financial statement fraud. International Research Journal of Management, IT and Social Sciences, 8(6), 619-629. https://doi.org/10.21744/irjmis.v8n6.1958 
1. H1 : Personal financial need has a negative effect on financial statement fraud.

In the normal operations of the bank, the banks could potentially face a variety of risks especially high risk in lending. To face the risk that, before the bank makes loans to customers, the bank must perform an accurate analysis to customers, then there is an agreement that is legally valid between lenders and y ang receiving a loan, the bank must monitor to customers, and customers must provide a guarantee and loan documentation are accurate to the bank in accordance with the standards that apply a right but, many factors are unexpected causes credit payments from the customer to be jammed or even customers can not make payment of credit due to bankruptcy and economic decline (mainly affected by the impact of a pandemic COVID-19 in Indonesia). This credit that may not be returned by the customer will then be referred to as bad debts (reserve for losses on receivables). This causes every loan (credit) that is disbursed has the possibility of not being returned. The amount of credit risk and the number of bad debts tend to have the potential to increase financial statement fraud. Weak supervision in the company will lead to a high opportunity for fraud in the company (Donelson et al., 2017). However, if banking companies implement good corporate governance, improve supervision, improve management of receivables and cash receipts, fraud can be reduced in the company.

This was also revealed by Hidayah \& Saptarini (2019); Suparmini et al. (2020), who said that if there is a good supervisory function through the ideal conditions of a company in the industry, managers will reduce the opportunity to commit fraud. If there is an increase in receivables, company managers will maintain the amount of receivables they have and try to increase the company's cash receipts from the amount of receivables rather than having to commit fraud.

2. H2: The nature of industry has a negative effect on financial statement fraud.

Several studies indicate that the incidence of audit failure is increasing related to the presence of auditor switching in the company (Skousen et al., 2009). Auditor switching in a company can be used as a benchmark for rationalization. Auditor switching at the company causes the new auditors to still do not understand the condition of the company as a whole so that if there is weak control then management may commit fraud that is not detected by external auditors. In this study, companies can intentionally perform auditor switching to eliminate traces of fraud that may have been found by previous auditors. Therefore, management's strategy to voluntarily replace auditors makes it easier for them to rationalize fraudulent financial statement behavior or consider fraudulent financial statements to be reasonable (rational). So the higher the auditor switching in the company, the more rational the company will think about doing financial statement fraud.

Chen \& Elder (2007), also stated that companies that often experience auditor switching tend to be more associated with indications of fraudulent financial reporting. According to Lou \& Wang (2009), a company can perform auditor switching to reduce the possibility of detecting financial statement fraud by the auditor. Sari \& Nugroho (2021), also state that rationalization affects financial statement fraud. Thinking that the rational will emerge when companies do not want the act of fraud it is known that the company will justify the manipulation of financial statements. The higher the intensity of independent auditor turnover, the easier it will be for management to rationalize fraudulent actions with the aim of committing financial statement fraud (Utama et al., 2018).

3. H3: Rationalization has a positive effect on financial statement fraud.

Variable director chage associated with the element capability. Director changes is the turn of the directors of the old to the new directors are more competent in overseeing the company's financial performance. The higher the intensity of the director changes in the company, the higher the supervision of the company's financial performance because the new directors are more competent and have the capability and implementation of good corporate governance in the company so that it will reduce indications of financial statement fraud in the company.

The director changes and the selective selection of new directors and replacing them with new directors who are more competent and have good capability are considered to be able to control the company's financial performance well. This was also expressed by Mintara \& Hapsari (2021), who said that a change of more competent directors was considered to be able to monitor the company's operations properly to reduce fraud. Research conducted by Siddiq et al. (2017); Septriani \& Handayani (2018); Mintara \& Hapsari (2021), also both prove that director change has a negative effect on indications of financial statement fraud.

4. H4: Director change has a negative effect on financial statement fraud.

CEO Duality or multiple positions in the company will reflect the high level of arrogance or superiority of the CEO in the company. CEOs who have multiple positions can use their power or arrogance for their own interests. The higher the CEO Duality in the company, the higher the level of CEO arrogance in the company. 
This condition will have an impact on the CEO being ineffective in carrying out his duties and responsibilities as a leader which will lead to financial statement fraud. The above statement is also supported by research conducted by Dechow et al. (2012), which shows that financial statement fraud related to earnings manipulation is dominated by management and dual positions by the CEO.

There are regulations in Indonesia that regulate concurrent positions, namely OJK Regulation Number 55/POJK.03/2016 which states that the board of directors is prohibited from holding concurrent positions as the board of commissioners (Putri \& Deviesa, 2017). Thus, companies in Indonesia are considered to have CEO duality if they have positions in other companies and the CEO concurrently serves on the board of commissioners. CEOs who perform duality positions tend to lead to fraudulent practices within the company. This statement is supported by the results of research conducted. Mohamed Yusof (2016), also said that the presence of a CEO who has many positions both internally and externally in the company can show the arrogance of the CEO. Multiple positions can cause the CEO's work to be disrupted because he is busy and lacks focus in carrying out responsibilities in the company so that this can allow fraud in the company (Crowe, 2011). Phanderoit, find that arrogance as measured by CEO duality has a positive effect on financial statement fraud. Yang et al. (2017), also stated that CEO duality will lead to weak corporate governance because the CEO cannot carry out supervision properly, causing fraud.

5. H5: CEO Duality has a positive effect on financial statement fraud.

\section{Methods}

This research will be conducted on banking companies listed on the Indonesia Stock Exchange (IDX) for the 20172020 period. The reason for choosing banking companies as research samples is because banking companies are the center of the economy in a country where the control carried out by the government is stronger than other industrial sectors. In carrying out these business activities, banks face various risks, both credit risk, market risk, operational risk and reputation risk, so that this has implications for the increased potential for fraudulent financial statements. The research population consists of all banking companies listed on the IDX. The sample used is a manufacturing company listed on the Stock Exchange which was selected through a purposive sampling technique with predetermined criteria. Data collected through non-participant observation by observing, recording, and studying the annual reports and financial reports of mining companies published by the Indonesia Stock Exchange (IDX) through www.idx.co.id. The analysis technique used is multiple linear regression analysis. This test aims to determine the effect of personal financial need, nature of industry, rationalization, director changes and CEO duality on financial statement fraud.

\section{Results and Discussions}

\section{Multiple linear regression analysis}

The analysis method in this study uses multiple linear regression equations to solve problems written based on the problem formulation that has been written, namely to determine the influence between two or more variables including the influence of personal financial need, nature of industry, rationalization, director changes, and CEO. Duality in financial statement fraud. The recapitulation of the results of multiple linear regression analysis is presented in Table 1 below:

Table 1

Recapitulation of multiple linear regression results

\begin{tabular}{|c|c|c|c|c|c|c|}
\hline & \multirow{2}{*}{ Model } & \multicolumn{2}{|c|}{ Unstandardized Coefficients } & \multirow{2}{*}{$\begin{array}{c}\text { Standardized Coefficients } \\
\text { Beta }\end{array}$} & \multirow{2}{*}{$\mathrm{t}$} & \multirow{2}{*}{ Sig. } \\
\hline & & $\mathrm{B}$ & Std. Error & & & \\
\hline \multirow[t]{3}{*}{1} & (Constant) & 0.035 & 0.050 & & 0.698 & 0.487 \\
\hline & $\mathrm{X} 1$ & -2.059 & 2,004 & -0.037 & -1.028 & 0.306 \\
\hline & $\mathrm{X} 2$ & -0.086 & 0.003 & -0.897 & $-24,678$ & 0.000 \\
\hline
\end{tabular}

Ayuningtyas, N. P. W., Sudana, I. P., Suartana, I. W., \& Mimba, N. P. S. H. (2021). Pentagon fraud perspective analysis in detecting indications of financial statement fraud. International Research Journal of Management, IT and Social Sciences, 8(6), 619-629. https://doi.org/10.21744/irjmis.v8n6.1958 


\begin{tabular}{cccccc}
\hline X3 & -0.035 & 0.051 & -0.026 & -0.690 & 0.492 \\
X4 & -0.109 & 0.051 & -0.080 & $-2,134$ & 0.035 \\
X5 & 0.060 & 0.057 & 0.038 & 1.036 & 0.302 \\
& Adjusted R Square & & 0,821 \\
& F & & \multicolumn{2}{c}{128,111} \\
& Sig. & & $0.000^{\mathrm{b}}$ & \\
\hline
\end{tabular}

Secondary Data, 2021

Based on the information in Table 1, the regression equation can be formulated as follows.

$$
\mathrm{Y}=0.035-2.059 \mathrm{X}_{1}-0.086 \mathrm{X}_{2}-0.035 \mathrm{X}_{3}-0.109 \mathrm{X}_{4}+0.060 \mathrm{X}_{5}
$$

\section{The effect of personal financial need on financial statement fraud}

The first hypothesis $\left(\mathrm{H}_{1}\right)$ states that personal financial need has a negative effect on financial statement fraud. The results of the multiple linear regression analysis in Table 1 state that the personal financial need variable as proxied by the insider share ownership ratio has a significance level of 0.306 which is higher than the research significance of 0.05 . This shows that personal financial need has no effect on indications of financial statement fraud in banking companies for the 2017-2020 period. Thus the first hypothesis in this study was rejected. The high or low proportion of banking company share ownership owned by insiders does not have an impact on financial statement fraud. The large number of insider share ownership will not affect the financial statement fraud and is also not an element of pressure to commit financial statement fraud for banking companies on the IDX for the 20172020 period. The results of descriptive statistics also show a low average of only $0.03 \%$ which means that of the 140 banking companies that were sampled, an average of only 0.03 percent implemented an insider stock ownership policy in banking companies from 2017 to 2020 so that it will not affect the financial statement fraud.

The results of this study are in accordance with research conducted by Suparmini et al. (2020), Sabatian \& Hutabarat (2020); Puspitha \& Yasa (2018), which states that personal financial need has no effect on financial statement fraud because there are many or at least insider's stock. Will not affect management policies in disclosing the company's performance and is not a pressure to commit fraudulent financial reporting. The results of this study do not support the research conducted by Skousen et al. (2009); Kusumaningsih (2017), which state that personal financial need as measured by insiders' stock ownership has been shown to have a negative effect in reducing indications of financial statement fraud because share ownership owned by managers and executives can equate the interests of managers and shareholders (Jensen \& Meckling, 1976). Managers can position themselves as potential shareholders because by owning company shares, managers will directly feel the benefits of every decision taken. Then if an error occurs, the manager will also be responsible for the error as a consequence of share ownership. This can be referred to as rewards and incentives for managers to improve company performance.

\section{The effect of the nature of industry on indications of financial statement fraud}

The second hypothesis $\left(\mathrm{H}_{2}\right)$ in this study stated that the nature of imdustry negative effect on the indication of financial statement fraud. Result analysis using linear regression berg you found in Table 1, the variable nature of the industry which is proxied by $\Delta$ Receivable ie the proportion of total accounts receivable and sales volumes (t) (t-1) have a level siginifikansi 0,000 which is smaller than $\alpha=0.05$ or $0.000<0.05$, it shows that the nature of the industry has an effect on the indications of financial statement fraud. The direction of the regression coefficient of the nature of industry variable in this study is negative at -0.086 . The results of the analysis show that the nature of the industry has a negative effect on indications of financial statement fraud. Thus the second hypothesis in this study is accepted.

The results of this study support the theory of fraud pentagon and good corporate governance that can affect the opportunities for fraudulent practices in the company. The principle of good corporate governance is carried out by the company by implementing the function of supervision and good management of accounts receivable. A banking company that manages receivables well, meaning that the bank has tried to collect from customers to increase cash receipts and the bank has carried out the principle of prudence (prudential banking) in disbursing credit in accordance with the affirmation of Article 2 of Law No. 8 of 1998 concerning banking, where the bank has been firm in conducting accurate and in-depth credit analysis to customers before making credit, applying the $5 \mathrm{C}$ principles (character, capacity, capital, collateral, and condition of economy) to see the eligibility of a credit applicant, the bank has implemented a 
valid agreement between the bank and the customer and has met legal requirements, the customer has had strong guarantees and documents before making credit, and the bank has tried to increase cash by collecting receivables from customers whose credit is due so that bad debts are low and reduce indications of fraud in company.

The results of this study are in accordance with the results of research conducted by Suparmini et al. (2020); Murtanto \& Kusumaningrum (2016), which state that the nature of industry has a negative influence on the detection of financial statement fraud. The condition of accounts receivable is a form of the nature of the industry which can be responded to with different reactions from the company's managers. According to Summers \& Sweeney (1998), also states that receivables and inventories require subjective assessment and must be wary of because they are often the object of manipulation of financial statements. To reduce fraudulent financial statements due to accounts receivable that are prone to being the object of manipulation, companies must implement good corporate governance or supervision from the company's internal parties to reduce fraud in financial statements. Donelson et al. (2017), also say that weak supervision in the company will lead to high fraud in the company.

\section{The effect of rationalization on indications of financial statement fraud}

The third hypothesis $\left(\mathrm{H}_{3}\right)$ in this study states that rationalization has a positive effect on indications of financial statement fraud. The results of the analysis using multiple linear regression contained in Table 1, the rationalization variable proxied by auditor switching and measured using a dummy variable (nominal scale) has a significance level of 0.492 , which is greater than $=0.05$ or $0.492>0.05$ it shows that auditor switching has no effect on indications of financial statement fraud. Thus the third hypothesis in this study was rejected. The results of this study support the results of research conducted by Apriliana \& Agustina (2017); Hidayah \& Saptarini (2019); Antawirya et al. (2019), which revealed that the rationalization described by auditor switching has no significant effect on financial statement fraud. This is because the $m$ anagement companies make the turn auditor because accustomed to engagements with the external auditors who have the professionalism and track record is good. An uditor professional as KAP Big 4 are able to understand the company as a whole to prevent the failure of auditors. The results of this study do not support the research conducted by Septriani \& Handayani (2018); Puspitha \& Yasa (2018); Mintara \& Hapsari (2021), which say that companies deliberately perform auditor switching to eliminate traces of fraud that may have been found by previous auditors. Therefore, management's strategy to voluntarily replace auditors makes it easier for them to rationalize and consider fraudulent behavior in financial statements to be reasonable (rational). So that the high intensity of auditor switching in the company shows that companies are increasingly positive and think rationally to commit financial statement fraud.

\section{The effect of director changes on indications of financial statement fraud}

The fourth hypothesis (H4) in this study states that director changes has a negative effect on indications of financial statement fraud. The results of the analysis using multiple linear regression contained in Table 1, the director change variable measured using a dummy variable (nominal scale) has a significance level of 0.035 which is smaller than $=0.05$ or $0.035<0.05$, this indicates that director changes had a significant negative effect on indications of financial statement fraud. Thus the fourth hypothesis in this study is accepted. The results of this study support research conducted by Siddiq et al. (2017); Septriani \& Handayani (2018); Mintara \& Hapsari (2021), which say that the use of the variable of director turnover to determine the potential for fraudulent financial statements proves that it has a significant negative effect on potential fraudulent financial statements. The replacement of more competent directors is considered to be able to oversee the company's operations well to reduce fraud. And research conducted which reveals that the director changes has an influence on financial statement fraud.

The results of this study are in accordance with the theory used, namely the fraud pentagon theory and good corporate governance. Wolfe \& Hermanson (2004), examined capability as one of the fraud risk factors behind the occurrence of fraud. The proxy for capability, namely the director changes, can affect the occurrence of fraudulent acts. Director change is the delegation of duties and authority from the old board of directors to the new board of directors with the aim of improving the performance of the previous directors who were less competent in overseeing the company's activities. However, changes in the board of directors can also cause the new director to experience a stress period which will result in the opening of opportunities to commit fraud and to reduce this occurrence, the company must implement good corporate governance or intense supervision of the new director in running the company so that it will reduce financial indications. Statement fraud in the company.

Ayuningtyas, N. P. W., Sudana, I. P., Suartana, I. W., \& Mimba, N. P. S. H. (2021). Pentagon fraud perspective analysis in detecting indications of financial statement fraud. International Research Journal of Management, IT and Social Sciences, 8(6), 619-629. https://doi.org/10.21744/irjmis.v8n6.1958 
The effect of CEO duality on indications of financial statement fraud

The fifth hypothesis $\left(\mathrm{H}_{5}\right)$ in this study states that CEO duality has a positive effect on indications of financial statement fraud. The results of the analysis using multiple linear regression contained in Table 1, the CEO duality variable measured using a dummy variable (nominal scale) has a significance level of 0.302 , which is greater than $=0.05$ or $0.302>0.05$, it indicates that CEO duality has no effect on indications of financial statement fraud. Thus the fifth hypothesis in this study was rejected. The results of this study do not support the research conducted by Phanderoit, in their research which states that the CEO holding multiple positions can be an indication of the occurrence of financial statement fraud in the company because multiple positions can cause the CEO's work to be disrupted because busy and less focused in carrying out responsibilities as a leader in the company so that this can allow fraud in the company

The results of this study do not support the theory used, namely the fraud pentagon theory. Arrogance in the theory of fraud pentagon which is described through CEO Duality which can affect the occurrence of fraud. CEOs who have multiple positions can use their power or arrogance for their own interests. The higher the CEO Duality in the financial statement, the higher the level of CEO arrogance in the company. Research results that do not support this theory most likely occur because the CEO of a banking company has multiple positions because there is a mutual agreement that allows the CEO to hold multiple positions and make more use of his position to improve the company's performance and to maintain his own performance in maintaining his position. Besides the observation of this study is only done for four years so that the variable CEO duality in this study have not been able to describe the effect on the financial statement fraud. Therefore, suggestions for future research can extend the range of observations to prove the effect of the CEO duality on indications of financial statement fraud.

\section{F statistic test (F Test)}

Model Feasibility Test (Test F) is used to test the feasibility or validity of a regression model 1 . Based on Table 1 shows the results of calculation of $F$ indicates a figure of 128.111 with 0.000 significance level of $\alpha=0.05$, so it can be concluded that the model is fit for use in research.

\section{Coefficient of determination analysis $\left(R^{2}\right)$}

Based on Table 1, it can be concluded that the value of adjusted R-square of 0.821 has a meaning that equal 82.1 percent of the variation change of the dependent variable is an indication of financial statement fraud can be explained by the independent variable is personal financial need, nature of industry, rationalization, director changes and CEO duality. While the remaining 17.9 percent is influenced by other factors that are not included in the regression model used.

\section{Conclusion}

The nature of industry and director change variables have an effect on indications of financial statement fraud in banking companies listed on the Indonesia Stock Exchange for the period $2017-2020$. The test results in this study state that the nature of industry and director change have a negative and significant effect on indications of financial statement fraud. This means that the higher nature of the industry that is supported by company condition that ideal in the industry. Then the high intensity of director changes in banking companies can indicate an indication of the occurrence of financial statement fraud will be lower.

This study supports the theory of fraud pentagon, namely the element of opportunity where if banks can use the opportunities of the nature of the bank industry well, the indications of fraudulent reports will be lower. Director changes is closely related to the theory of fraud pentagon that capability. The company carries out the turn of a new director to the old director who has the capability is better to run the company both aimed at reducing indications of fraud financial statements in the banking company. This study also supports the theory of good corporate governance which is a set of rules that determine the relationship between shareholders, company managers, creditors, the government, employees and other internal and external stakeholders related to their rights and obligations, or can be called a system that regulates and controls a company (FCGI, 2006). Nature of industry describes the principle of corporate governance theory, namely transparency, which means that in order to maintain the ideal condition of banks, 
banking companies have prioritized openness in the activities of disclosure of receivables, collection of receivables and cash receipts as well as the process of supervision in lending to avoid the risk of bad loans (customers who cannot pay the credit bill).

The existence of the principle of transparency will reduce fraud in financial statements because management prioritizes transparency in cash flow management and collection of receivables so that banks can fulfill their obligations to all parties who withdraw or withdraw their deposits at any time. Readiness to meet these obligations at any time becomes increasingly important given the role of banks as institutions that facilitate the flow of payments. The ideal and healthy nature of the industry also shows justice for all stakeholders involved as well as people who make savings and loans in banks and use information from the company's financial statements to make decisions. Director changes describes the principle of responsibility in the theory of corporate governance which means that the change of old directors to new, more competent directors must prioritize the principle of responsibility in supervising and managing company activities.

Conflict of interest statement

The authors declared that they have no competing interests.

Statement of authorship

The authors have a responsibility for the conception and design of the study. The authors have approved the final article.

\section{Acknowledgments}

We are grateful to two anonymous reviewers for their valuable comments on the earlier version of this paper.

Ayuningtyas, N. P. W., Sudana, I. P., Suartana, I. W., \& Mimba, N. P. S. H. (2021). Pentagon fraud perspective analysis in detecting indications of financial statement fraud. International Research Journal of Management, IT and Social Sciences, 8(6), 619-629. https://doi.org/10.21744/irjmis.v8n6.1958 


\section{References}

Antawirya, R. D. E. P., Putri, I. G. A. M. D., Wirajaya, I. G. A., Suaryana, I. G. N. A., \& Suprasto, H. B. (2019). Application of fraud pentagon in detecting financial statement fraud. International Research Journal of Management, IT and Social Sciences, 6(5), 73-80.

Apriliana, S., \& Agustina, L. (2017). The analysis of fraudulent financial reporting determinant through fraud pentagon approach. Jurnal Dinamika Akuntansi, 9(2), 154-165.

Bai, Y. C., Han, X., Jiang, C., \& Bi, R. G. (2014). A response-surface-based structural reliability analysis method by using non-probability convex model. Applied Mathematical Modelling, 38(15-16), 3834-3847. https://doi.org/10.1016/j.apm.2013.11.053

Bikker, J. A., \& Haaf, K. (2002). Competition, concentration and their relationship: An empirical analysis of the banking industry. Journal of banking \& finance, 26(11), 2191-2214. https://doi.org/10.1016/S03784266(02)00205-4

Chen, K. Y., \& Elder, R. J. (2007). Fraud risk factors and the likelihood of fraudulent financial reporting: Evidence from statement on Auditing Standards No. 43 in Taiwan. Syracuse University Whitman School of Management Syracuse.

Cressey, D. R. (1953). Other people's money; a study of the social psychology of embezzlement.

Crowe, H. (2011). Why the fraud triangle is no longer enough. Horwath, Crowe LLP.

Dechow, P. M., Hutton, A. P., Kim, J. H., \& Sloan, R. G. (2012). Detecting earnings management: A new approach. Journal of accounting research, 50(2), 275-334.

Donelson, D. C., Ege, M. S., \& McInnis, J. M. (2017). Internal control weaknesses and financial reporting fraud. Auditing: A Journal of Practice \& Theory, 36(3), 45-69.

Hidayah, E., \& Saptarini, G. D. (2019). Pentagon Fraud Analysis in Detecting Potential Financial Statement Fraud of Banking Companies in Indonesia. Proceeding UII-ICABE, 1(1), 89-102.

Jensen, M. C., \& Meckling, W. H. (1976). Theory of the firm: Managerial behavior, agency costs and ownership structure. Journal of financial economics, 3(4), 305-360.

Kustina, K.T., Dewi, G.A.A.O., Prena, G.D., Suryasa, W. (2019). Branchless banking, third-party funds, and profitability evidence reference to banking sector in Indonesia. Journal of Advanced Research in Dynamical and Control Systems, 11(2), 290-299.

Kusumaningsih, L. P. S. (2017). Penerimaan diri dan kecemasan terhadap status narapidana. Intuisi: Jurnal Psikologi Ilmiah, 9(3), 234-242.

Loebbecke, J. K., Eining, M. M., \& Willingham, J. J. (1989). Auditors experience with material irregularitiesfrequency, nature, and detectability. Auditing-A Journal of Practice \& Theory, 9(1), 1-28.

Lou, Y. I., \& Wang, M. L. (2009). Fraud risk factor of the fraud triangle assessing the likelihood of fraudulent financial reporting. Journal of Business \& Economics Research (JBER), 7(2).

Mata, J. (2011). Interpretation of concrete dam behaviour with artificial neural network and multiple linear regression models. Engineering Structures, 33(3), 903-910. https://doi.org/10.1016/j.engstruct.2010.12.011

Mehta, E. (2016). Literature review on HR practice in banking sector. International research journal of engineering, IT \& scientific research, 2(7), 90-97.

Mintara, M. B. M., \& Hapsari, A. N. S. (2021). Pendeteksian Kecurangan Pelaporan Keuangan Melalui Fraud Pentagon Framework. Perspektif Akuntansi, 4(1), 35-58.

Mohamed Yusof, K. (2016). Fraudulent financial reporting: An application of fraud models to malaysian public listed companies (Doctoral dissertation, University of Hull).

Murtanto, M., \& Kusumaningrum, A. W. (2016, October). Analisis Pengaruh Fraud Diamond Dalam Mendeteksi Kecurangan Laporan Keuangan. In Seminar Nasional UNIBA Surakarta (Vol. 2, No. 1, pp. 125-138).

Oktafiana, N. F., \& Sari, S. P. (2019, June). Analisis Fraud Laporan Keuangan Dengan Wolfe \& Hermanson's Fraud Diamond Model Pada Perusahaan LQ45 Di Bursa Efek Indonesia. In Prosiding Seminar Nasional \& Call For Paper (pp. 246-258).

Puspitha, M. Y., \& Yasa, G. W. (2018). Fraud pentagon analysis in detecting fraudulent financial reporting (study on Indonesian capital market). International Journal of Sciences: Basic and Applied Research, 42(5), 93-109.

Putri, L. L., \& Deviesa, D. (2017). Pengaruh CEO Duality terhadap financial performance dengan earnings management sebagai variabel intervening. Business Accounting Review, 5(1), 169-180.

Putriasih, K., Herawati, N. N. T., \& Wahyuni, M. A. (2016). Analisis Fraud Diamond Dalam Mendeteksi Financial Statement Fraud: Studi Empiris Pada Perusahaan Manufaktur Yang Terdaftar Di Bursa Efek Indonesia (Beu) Tahun 2013-2015. E-JournalS1 Ak Universitas Pendidikan Ganesha, 6(3). 
Reinhart, C. M., \& Rogoff, K. S. (2013). Banking crises: an equal opportunity menace. Journal of Banking \& Finance, 37(11), 4557-4573. https://doi.org/10.1016/j.jbankfin.2013.03.005

Rengganis, R. M. Y. D., Sari, M. M. R., Budiasih, I. G. A. N., Wirajaya, I. G. A., \& Suprasto, H. B. (2019). The fraud diamond: element in detecting financial statement of fraud. International research journal of management, IT and social sciences, 6(3), 1-10.

Rezaee, Z. (2005). Causes, consequences, and deterence of financial statement fraud. Critical perspectives on Accounting, 16(3), 277-298. https://doi.org/10.1016/S1045-2354(03)00072-8

Sabatian, Z., \& Hutabarat, F. M. (2020). The Effect Of Fraud Triangle In Detecting Financial Statement Fraud. Jurnal Akuntansi, 10(3), 231-244.

Sari, S. P., \& Nugroho, N. K. (2021, March). Financial Statements Fraud dengan Pendekatan Vousinas Fraud Hexagon Model: Tinjauan pada Perusahaan Terbuka di Indonesia. In Annual Conference of Ihtifaz: Islamic Economics, Finance, and Banking (pp. 409-430).

Saunders, A. (1999). Consolidation and universal banking. Journal of Banking \& Finance, 23(2-4), 693-695. https://doi.org/10.1016/S0378-4266(98)00103-4

Septriani, Y., \& Handayani, D. (2018). Mendeteksi Kecurangan Laporan Keuangan dengan Analisis Fraud Pentagon. Jurnal Akuntansi Keuangan Dan Bisnis, 11(1), 11-23.

Siddiq, F. R., Achyani, F., \& Zulfikar, Z. (2017). Fraud Pentagon dalam Mendeteksi Financial Statement Fraud.

Skousen, C. J., Smith, K. R., \& Wright, C. J. (2009). Detecting and predicting financial statement fraud: The effectiveness of the fraud triangle and SAS No. 99. In Corporate governance and firm performance. Emerald Group Publishing Limited.

Sousa, S. I. V., Martins, F. G., Alvim-Ferraz, M. C. M., \& Pereira, M. C. (2007). Multiple linear regression and artificial neural networks based on principal components to predict ozone concentrations. Environmental Modelling \& Software, 22(1), 97-103. https://doi.org/10.1016/j.envsoft.2005.12.002

Summers, S. L., \& Sweeney, J. T. (1998). Fraudulently misstated financial statements and insider trading: An empirical analysis. Accounting Review, 131-146.

Suparmini, N. K., Ariyanto, D., \& Wistawan, I. M. A. P. (2020). Pen-gujian Fraud Diamond Theory Pada Indikasi Financial Statement Fraud Di Indonesia. E-Jurnal Akuntansi, 30(6), 1441-1457.

Surya, S., Mishra, A., Laha, A., Jain, P., \& Sankaranarayanan, K. (2018). Unsupervised neural text simplification. arXiv preprint arXiv:1810.07931.

Topp, L., Barker, B., \& Degenhardt, L. (2004). The external validity of results derived from ecstasy users recruited using purposive sampling strategies. Drug and alcohol dependence, 73(1), 33-40. https://doi.org/10.1016/j.drugalcdep.2003.09.001

Utama, Y. J., Ambariyanto, A., Zainuri, M., Darsono, D., Setyono, B., \& Putro, S. P. (2018, May). Sustainable development goals as the basis of university management towards global competitiveness. In Journal of Physics: Conference Series (Vol. 1025, No. 1, p. 012094). IOP Publishing.

Uyanık, G. K., \& Güler, N. (2013). A study on multiple linear regression analysis. Procedia-Social and Behavioral Sciences, 106, 234-240. https://doi.org/10.1016/j.sbspro.2013.12.027

Wolfe, D. T., \& Hermanson, D. R. (2004). The fraud diamond: Considering the four elements of fraud.

Zhou, W., \& Kapoor, G. (2011). Detecting evolutionary financial statement fraud. Decision support systems, 50(3), 570-575. https://doi.org/10.1016/j.dss.2010.08.007

Ayuningtyas, N. P. W., Sudana, I. P., Suartana, I. W., \& Mimba, N. P. S. H. (2021). Pentagon fraud perspective analysis in detecting indications of financial statement fraud. International Research Journal of Management, IT and Social Sciences, 8(6), 619-629. https://doi.org/10.21744/irjmis.v8n6.1958 